\title{
Multicenter Verification of a Harmonized Test Method for Human Leukocyte Antigen Flow Cytometry Crossmatching
}

\author{
Younhee Park ${ }^{1 \oplus}$, Myoung Hee Park ${ }^{2 \oplus}$, Borae G. Park ${ }^{3 \oplus}$, Eun-Jee Oh ${ }^{4 \oplus}$, Hae In Bang ${ }^{5 \oplus}$, Jong-Han Lee ${ }^{6 \oplus}$, \\ and Eun-Suk Kang ${ }^{7}$ \\ ${ }^{1}$ Department of Laboratory Medicine, Severance Hospital, Yonsei University College of Medicine; ${ }^{2}$ Korea Organ Donation Agency \\ Laboratory; ${ }^{3}$ Department of Laboratory Medicine, Korea University Guro Hospital; ${ }^{4}$ Department of Laboratory Medicine, Seoul \\ St. Mary's Hospital, College of Medicine, The Catholic University of Korea; ${ }^{5}$ Department of Laboratory Medicine, Soonchunhyang \\ University Seoul Hospital, Seoul; 'Department of Laboratory Medicine, Yonsei University Wonju College of Medicine, Wonju; \\ 'Department of Laboratory Medicine and Genetics, Samsung Medical Center, Sungkyunkwan University School of Medicine, \\ Seoul, Korea
}

\section{Corresponding author: \\ Eun-Suk Kang \\ Department of Laboratory Medicine and Genetics, Samsung Medical Center, Sungkyunkwan University School of Medicine, 81 Irwon-ro, Gangnam-gu, Seoul 06351, Korea \\ Tel +82-2-3410-2703 \\ E-mail eskang@skku.edu}

Received: March 5, 2021

Revised: April 16, 2021

Accepted: April 21, 2021
This is an Open Access article distributed under the terms of the Creative Commons Attribution Non-Commercial License (http://creativecommons.org/licenses/ by-nc/4.0) which permits unrestricted non-commercial use, distribution, and reproduction in any medium, provided the original work is properly cited.
Background: Flow cytometry crossmatch (FCXM) is the most sensitive method currently used for human leukocyte antigen (HLA) crossmatches. The FCXM test methods and cut-off values used to determine the positive reaction vary significantly in different laboratories. To obtain comparable FCXM results from different laboratories and to use these results in deciding the compatibility between a donor and a recipient in organ transplantation, a standardized protocol needs to be established. In this study, we attempted to develop a harmonized test method and verify its performance with that of the different laboratories' methods through a multicenter comparison.

Methods: The harmonized method was determined via a literature review and a survey that included seven laboratories. For the harmonized method, cell number, serum amount, pronase treatment for B cell FCXM, incubation temperature and time, and anti-human immunoglobulin $G$ fluorescein isothiocyanate conjugate were standardized. Two trials of FCXM using one cell and three sera samples in each trial were performed, and the results of the laboratories' methods versus those of the harmonized method were analyzed.

Results: Compared to the laboratory methods, the harmonized method showed increased agreement with consensus positive/negative results (75/84, $89.3 \%$ vs. $81 / 84,96.4 \%$ ) and a significantly decreased coefficient of variation among different laboratories in detecting the median fluorescence intensity (MFI) ratio values ( $88.3 \%$ vs. $55.2 \%, P=0.0003$ ).

Conclusions: When the same protocol for the FCXM method is used, an increased consensus of positive/negative results and decreased variation of the MFI ratios from different laboratories can be obtained. Implementation of a harmonized and standardized protocol is needed in all domestic laboratories that perform the FCXM tests.

(Lab Med Qual Assur 2021;43:152-161)

Key Words Organ transplantation, Human leukocyte antigen, Flow cytometry crossmatch, Harmonization, Multicenter verification 
서론

보체매개 세포독성 교차시험(complement-dependent cytotoxicity crossmatch, CDC-XM)은 신장 이식에서 공여자 와 수혜자 간의 적합성을 평가하기 위해 오래 전부터 사용되어 온 검사방법이지만, 공여자 특이항체(donor-specific antibody, $\mathrm{DSA})$ 의 검출 민감도 향상을 위해 개선된 검사방법들이 개발되어 사용되고 있다. 유세포교차시험(flow cytometry crossmatch, $\mathrm{FCXM}$ )은 현재 사용되는 검사 중 가장 민감한 교차시험 검사법 으로 $\mathrm{CDC}-\mathrm{XM}$ 검사로는 검출이 어려운 적은 양의 $\mathrm{DSA}$ 를 검출 하며, CDC-XM 검사보다 단시간 내에 검사가 이루어지므로 국내 외에서 검사를 시행하는 기관 수도 증가하고 있다[1-4]. 국내에 서는 약 34 개 기관이 FCXM을 시행하고 있다[5]. 다양한 연구에 서 낮은 역가의 DSA가 존재하더라도 초회 이식과 재이식 모두에 서 이식 후 이식 신장의 소실과 관련된 상대적 위험의 증가가 보 고되고 있다[2,6-10]. 2018년 9월부터 시행된 “장기 등 이식에 관 한 법률 시행규칙” 제15조 제2항에 의하면 국립장기조직혈액관 리원(Korean Network for Organ Sharing)의 국내 뇌사자 장 기이식을 위한 적합한 수혜자 선별을 위한 검사법으로 CDC-antihuman globulin법과 더불어 FCXM법을 실시한 경우에는 결과 를 cut-off value와 median fluorescent intensity (MFI) ratio 까지 포함하여 보고하도록 개정되었다.

CDC-XM의 경우 American Society of Histocompatibility and Immunogenetics (ASHI) 가이드라인을 근간으로 표준화 된 방법이 널리 시행되고 있으나, FCXM법은 검사를 시행하는 기 관에 따라 검사방법이 다양하며, 결과를 판정하는 단위도 MFI ratio (MFI value of serum/MFI value of negative control serum) 또는 median channel shift로 검사기관에 따라 다른 것 으로 보고되고 있다. 처음으로 광범위하게 이루어진 2015년 국내 human leukocyte antigen (HLA) 교차시험 현황조사를 통해 국 내에서도 동일한 상황임을 확인하였고, 양성을 판단하는 기준도 $\mathrm{T}$ 세포의 경우 1.1-2.0, B세포의 경우 1.1-3.2로 다양하였다[11]. 이로 인하여 민감한 교차시험 검사법임에도 불구하고 아직까지는 최종 판정검사로 인정받기 어려운 실정이다. 이식검사 기관 간의 검사결과의 호환성과 뇌사자 장기이식을 위한 적합한 수혜자 선정 을 위한 판정검사로 이용하기 위해서는 표준화된 검사방법의 정립 을 통한 객관적인 검사결과를 도출하는 것이 필수적이다.

본 연구에서는 국내외 검사방법 검토를 통하여 결정한 공통검 사법(harmonized test method)을 여러 기관에 적용하여 기관 내 및 기관 간 비교검증을 시도함으로써 FCXM의 표준화를 모색하 기 위한 기반을 마련하고자 하였다.

\section{재료 및 방법}

\section{1. 참여기관}

국내 7개 기관(가톨릭대학교 서울성모병원, 고려대학교 구로병 원, 삼성서울병원, 세브란스병원, 순천향대학교 부속 서울병원, 원 주세브란스기독병원, 재단법인 한국장기조직기증원 코다의원)이 자발적으로 참여하였는데, 기관 간 비교 시 변수를 줄이기 위해 당 일에 검체 전달이 가능한 지역 내 기관들이 우선 대상이 되었다.

\section{2. 기존검사법 설문조사}

참여기관들을 대상으로 검사결과에 영향을 줄 수 있는 요인을 포함하여 검사방법에 대한 설문조사를 시행하였다. 설문내용에는 세포분리 방법 및 사용 세포 수, 각종 시약 정보 및 사용량, 시행방 법 그리고 판정을 위한 기준을 포함하였다.

\section{3. 공통검사법의 결정}

$\mathrm{ASHI}$ 검사방법과 국외 성능이 인정된 검사법에 대한 문헌을 분 석하여 검사결과에 영향을 줄 수 있는 요인을 찾고 공통검사법에 포함되어야 할 단계별 검사방법을 참조하였다[12,13]. 설문조사 결과와 문헌고찰 결과를 토대로 7 개 참여기관의 담당전문의가 회 의를 통해 공통검사법을 결정하였다. 각 기관의 상황에 따라 공통 검사법으로 일치시키기 어렵거나 검사결과에 미치는 영향이 적을 것으로 판단되는 세포분리 방법, assay platform, CD3와 CD19 의 항체 종류, 유세포 분석기의 종류, 분석 세포 수, 양성 판정기준 등은 각 기관의 기존 방법을 사용하기로 하였다.

\section{4. 시험용 세포 및 혈청의 제조 및 배포}

2차에 걸쳐 각 회차당 다양한 항-HLA 항체의 역가를 가진 3 개 의 혈청과 세포용 전혈을 제조하여 참여기관에 배포하였다. 배포 한 검체는 건강한 자원자로부터 헌혈을 통해 얻은 전혈 $30 \mathrm{~mL}$ (citrate-phosphate-adenine anticoagulant, CPDA-1)과 혈청 각 $1 \mathrm{~mL}$ 로 구성하였고, 전혈은 1 차와 2차에 동일한 자원자로부터 얻었다. 배포 당일 아침에 전혈을 준비하고, 미리 준비한 혈청과 전혈을 빠른 배송을 통해 각 참여기관이 당일에 검체를 수령한 후 검사가 가능하도록 하였다. 시험세포의 HLA 형별 결과와 각 혈청 의 DSA 정보는 검사결과를 모두 취합한 후 각 참여기관에 전달하 였다(Table 1).

\section{Human leukocyte antigen 교차시험}

모든 참여기관은 수령한 세포와 혈청을 조합하여 각 기관의 기 존검사법과 공통검사법의 두 가지 방법으로 검사를 시행하였으 며, 검체 수령 1 주일 이내에 결과를 보고하도록 하였다. 각 기관 
내 검사방법 간의 결과 일치도와 기관 간 결과의 일치도 그리고 $\mathrm{MFI}$ ratio의 변이계수(coefficient of variation, CV) 분석을 시행 하였다. 기존검사법과 공통검사법의 CV 차이는 Friedman test 를 이용하여 비교하였으며(Analyse-it, ver. 5.68; Analyse-it
Software Ltd., Leeds, UK), P-value 0.05 미만인 경우 통계적으 로 유의한 것으로 판정하였다. 전체 시험과정을 그림으로 표기하 였다(Fig. 1).

Table 1. HLA antibodies and MFI values of DSAs in sera used for the first and second trials

\begin{tabular}{|c|c|c|c|c|}
\hline Trial & Serum & DSAs (MFI)*: HLA class I & CPRA $\%$ & DSAs $(\mathrm{MFI})^{\star}:$ HLA class II \\
\hline \multirow[t]{3}{*}{$1 \mathrm{st}$} & $\mathrm{S}-1$ & $\begin{array}{l}\text { A24 (4,596), A31 }(4,693), \text { B35 }(13,911), \text { B54 } \\
(12,301) ; \text { sum }(35,501)\end{array}$ & 100 & DR8 (2,826), DQ6 (1,637); sum $(4,463)$ \\
\hline & $\mathrm{S}-2$ & A24 (1,846), B35 $(4,217) ; \operatorname{sum}(6,063)$ & 98 & DR8 (1,684), DR15 (3,200), DQ6 $(17,485) ; \operatorname{sum}(22,369)$ \\
\hline & $\mathrm{S}-3$ & None & 0 & None \\
\hline \multirow[t]{3}{*}{ 2nd } & S-4 & B54 $(4,890) ;$ sum $(4,890)$ & 87 & None \\
\hline & S-5 & $\begin{array}{l}\text { A24 (1,928), A31 }(18,244), \text { B35 }(19,164), \text { B54 } \\
(12,196) ; \text { sum }(51,532)\end{array}$ & 100 & $\begin{array}{l}\text { DR8 }(1,897) \text {, DR15 }(8,510) \text {, DQ6 }(11,816) \text {, DR51 }(6,353) ; \\
\text { sum }(28,576)\end{array}$ \\
\hline & S-6 & Cw1 (1,784); sum $(1,784)$ & 58 & $\begin{array}{l}\text { DR8 (5,304), DR15 (5,478), DQ6 (619), DR51 }(2,639) \\
\text { sum }(14,040)\end{array}$ \\
\hline
\end{tabular}

Abbreviations: HLA, human leukocyte antigen; MFI, median fluorescence intensity (from HLA antibody single antigen bead assay using One Lambda LABScreen Single Antigen kit); DSAs, donor specific antibodies; cPRA, calculated percent reactive antibody.

*HLA antibody specificities (MFI values) against the same cell used in the first and second trials: A24, A31, B35, B54, Cw1, Cw7, DR8, DR15, DQ6, DQ6.

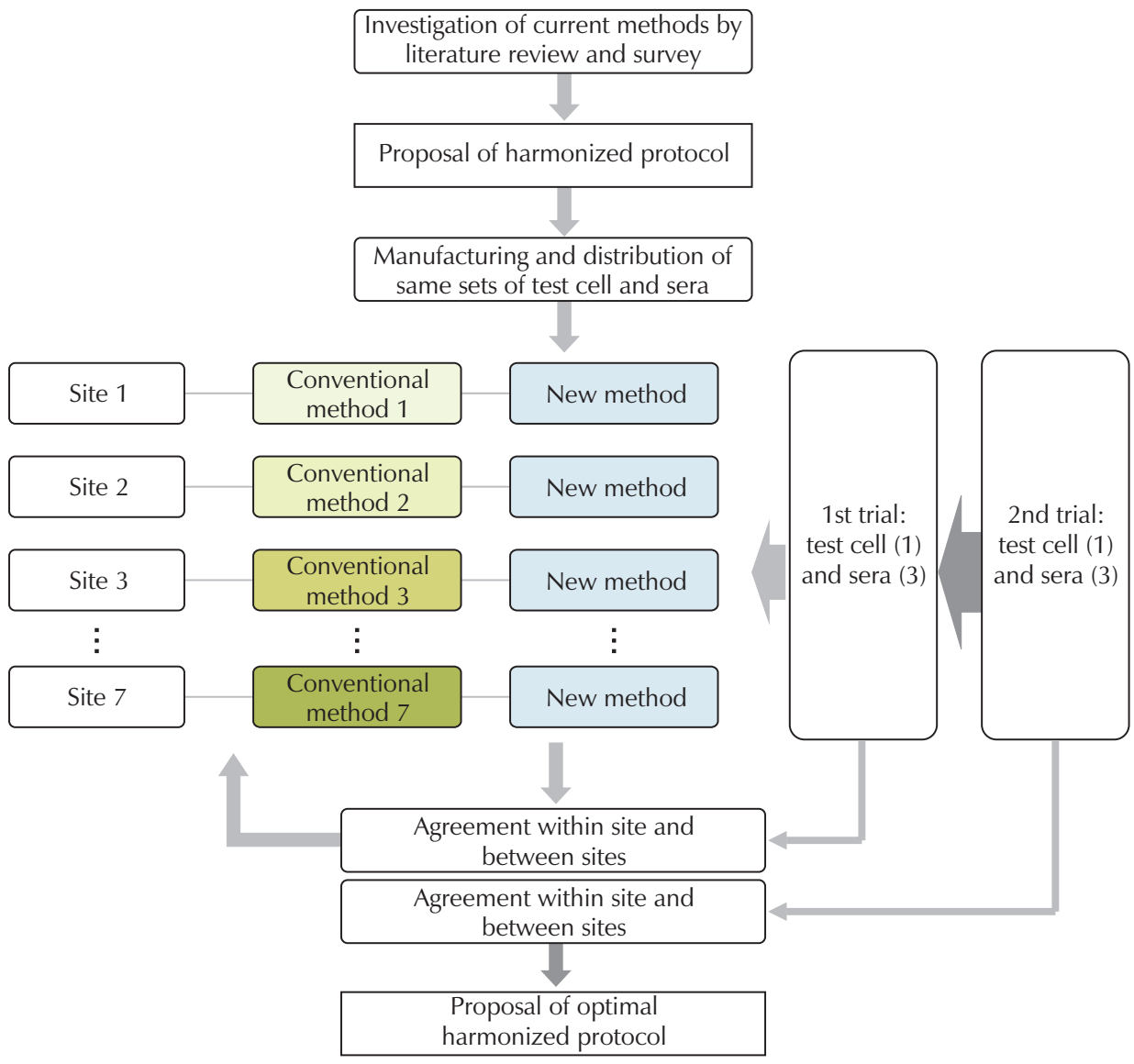

Fig. 1. Schematic diagram of study design. 


\section{결과}

\section{1. 유세포교차시험 공통검사법 결정}

\section{1) 문헌고찰 및 참여기관의 기존검사법 설문조사}

$\mathrm{ASHI}$ 검사방법[12]과 캐나다 내 다기관 표준화 방법을 적용하 여 기관 간 결과 변이를 성공적으로 줄인 것으로 보고한 문헌[13] 의 프로토콜을 각 단계별로 비교 분석하고, 설문조사를 통해 얻은 각 기관 간 조건들을 비교해 본 결과, $\mathrm{FCXM}$ 시 사용하는 세포의 종류와 수, 세포와 혈청의 배양온도 및 시간, 세척 횟수 및 방법, 양 성 판정기준 등 거의 모든 항목에 대하여 각 기관별로 다양한 조건 으로 검사를 시행하고 있음을 확인하였다. 세포분리 방법에 대한 내용을 Table 2에, 교차시험 방법과 시약 및 결과 판정에 대한 내 용을 Table 3에 정리하였다.

\section{2) 공통검사법 결정}

결정한 공통검사법은 Table 2 와 Table 3 의 마지막 세로단에 정리하였다. 세포를 분리하는 방법은 비중차이를 이용한 밀도구 배원심법으로 말초혈액단핵구를 분리하여 사용하는 기관과 음 성 선택방법(EasySep kits; STEMCELL Technologies Inc., Vancouver, Canada)을 이용한 총 림프구 혹은 T세포와 B세포를 각각 분리하여 사용하는 기관으로 나뉘었는데, 각 기관의 방법에 따라 시행하도록 하였다. 공통검사법의 주요 사항은 다음과 같다. Pronase는 B세포 교차시험에 대해서만 처리하기로 하였으며, T 세포와 B세포를 분리하지 않고 한 튜브에서 검사하는 기관의 경우 에는 pronase 처리용과 비처리용으로 tube를 나누어 검사를 시 행하도록 하였고, 농도, 처리 시간과 반응온도를 단일화하였다. 세 포부유액과 혈청은 동일한 양인 $30 \mu \mathrm{L}$ 로 1:1의 비율이 되도록 하 였으며, 세포 수는 매 tube마다 $3.0 \times 10^{5}$ 정도가 포함되도록 하였 다. 배양조건을 실온으로 통일하여 별도 냉장 배양이 필요하지 않 도록 하였다. 세척조건의 시간과 횟수를 감소시켜 검사시간을 절 감할 수 있도록 하였다. 세척액의 경우는 세척 시 세포의 유실률 을 낮추기 위해 $2 \%$ fetal calf serum 혹은 $0.2 \%$ bovine serum albumin를 포함하도록 하였다. 2차 항체인 immunoglobulin G (IgG)-fluorescein isothiocyanate (FITC)는 FITC conjugated $\mathrm{F}\left(\mathrm{ab} \mathrm{b}^{\prime}\right)_{2}$ fragment goat anti-human IgG, $\mathrm{Fc}_{\gamma}$ fragment specific (Jackson ImmunoResearch Laboratories Inc., West Grove, PA, USA)로 단일화하기 위해 시험세포 및 혈청과 함께 IgG-FITC도 각 기관에 배포하여 사용하도록 하였다. IgG-FITC의 tube당 사용량은 $\mathrm{ASHI}$ manual에서 권장하는 $0.25 \mu \mathrm{L}$ 로 정하였 으며[12], CD3와 CD19의 양은 각 기관마다 다르지만 항체 혼합 액(antibody cocktail)의 양은 phosphate buffered saline을

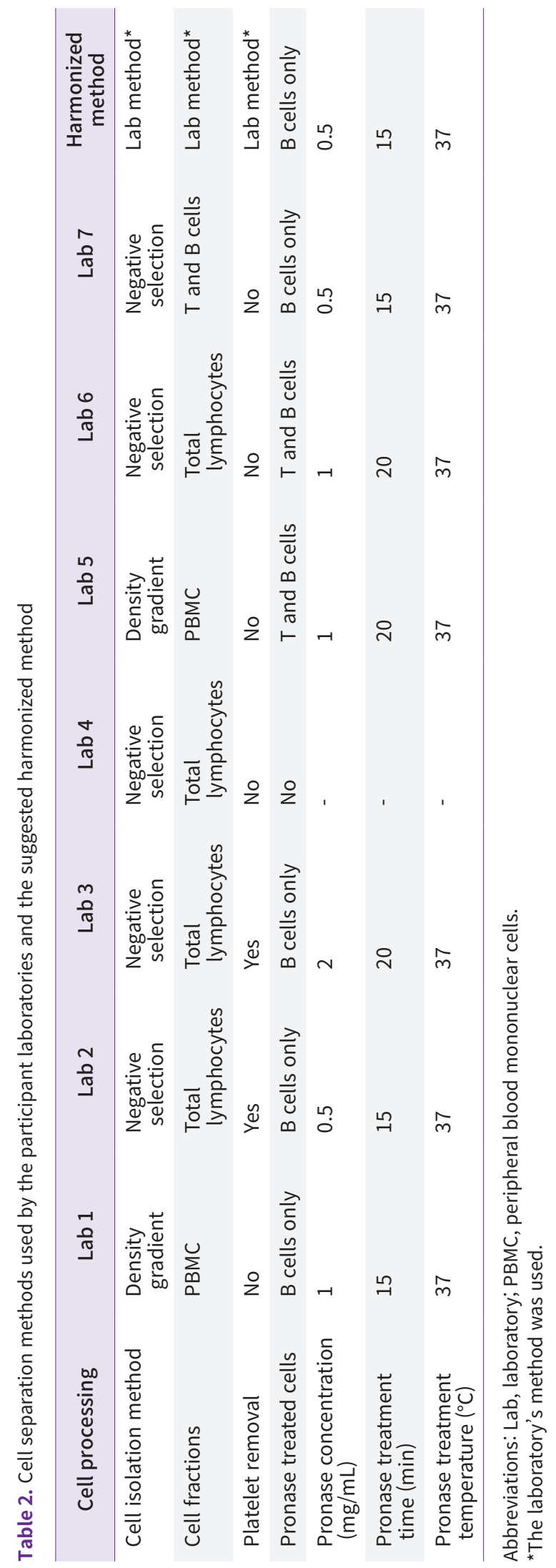




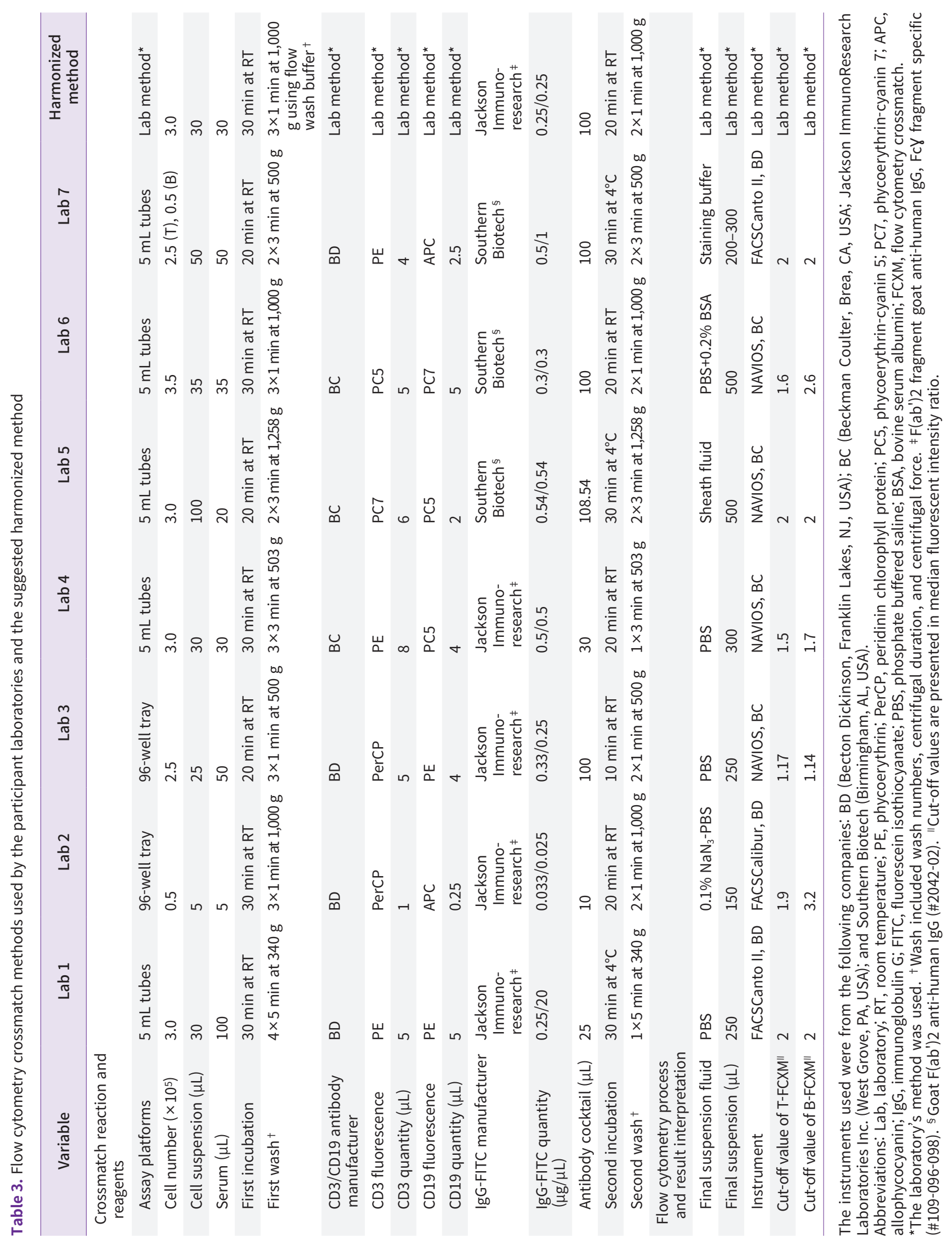


섞어 tube당 $100 \mu \mathrm{L}$ 를 첨가하도록 하였다. 양성 및 음성의 판정은 각 기관의 cut-off value를 기준으로 판정하도록 하였다(Table 3).

\section{2. 유세포교차시험 결과}

각 기관에서 기존검사법 결과와 합의(consensus) 결과와의 일치율은 1차 평가에서 $88.1 \%$ (37/42), 2차 평가에서 $90.5 \%$ (38/42)였으며, 공통검사법으로 시행한 결과와 합의 결과와의 일치율은 1차 평가에서 $97.6 \%$ (41/42), 2차 평가에서 95.2\% (40/42)였다. 1차, 2차 평가를 종합하면 기존검사법에서 $89.3 \%$ (75/84), 공통검사법에서 $96.4 \%$ (81/84)의 결과가 합의 결과와 일치하였다(Tables 4, 5).

\section{1) T세포 FCXM}

1차와 2차 평가에 사용된 혈청 중 각각 2개씩(S-1, S-2와 S-4, S-5)은 중등도 이상의 MFI를 가지는 class I DSA 양성 혈청이었으 며, 나머지 1 개는 각각 DSA 음성(S-3)과 낮은 MFI의 class I (CW) DSA (S-6)를 가진 혈청이었다(Table 1).

1 차 평가에서 7 개 기관 중 3 개 기관에서 S-2에 대해 T세포 $\mathrm{FCXM}$ 에 대해 위음성 결과를 보고하였으나, 이 중 2개 기관은 공 통검사법으로 시행한 결과에서는 양성으로 보고하였다. 2차 평가 에서 S-4 혈청에 대해 기관 7은 기존검사법에서는 위음성 결과를 보고하였으나, 공통검사법으로 시행한 결과 양성으로 보고하였으 며, 기관 6 의 경우에는 공통검사법에서 위음성 결과를 보고하였 다. 낮은 MFI의 HLA-CW DSA를 가지는 S-6의 경우에는 모든 기 관에서 공통검사법과 기존검사법 결과에서 음성으로 보고하였다 (Table 4).

\section{2) B세포 FCXM}

1 차와 2차 평가에 사용된 혈청 중 각각 2개씩(S-1, S-2와 S-5, S-6)은 중등도 이상의 MFI를 가지는 class II DSA 양성 혈청이었 으며, 나머지 1개씩은 DSA 음성(S-3, S-4) 혈청이었다(Table 1).

1 차 평가에서 S-3에 대해서 2개 기관에서 위양성 결과를 보고 하였으나, 공통검사법으로 시행한 결과에서는 모두 음성 결과를 보고하였다. 2차 평가에서 S-4 혈청에 대해 기관 6은 기존검사법 에서 위음성을 보고하였으나, 공통검사법으로 시행한 결과에서 양 성으로 보고하였다. S-6의 경우에는 기관 4 와 기관 5 에서 기존검 사법에서 위음성으로 보고하였으나, 공통검사법에서는 양성으로 보고하였고, 기관 6 의 경우에는 공통검사법에서 위음성으로 보고 하였다(Table 5). MFI ratio는 1차와 동일하게 기관 1 과 기관 3에 서는 공통검사법에서 낮게, 기관 2 를 제외한 기관 $4,5,6,7$ 에서는 공통검사법에서 증가한 결과를 보였다.

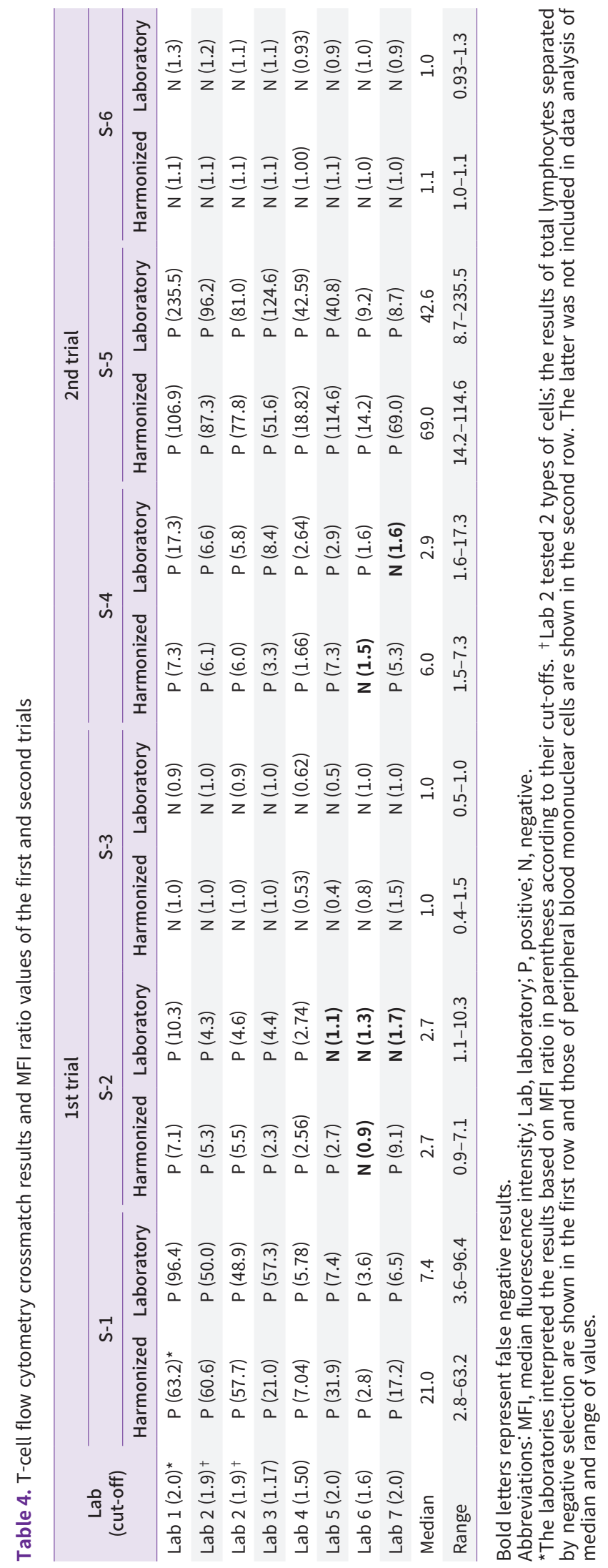




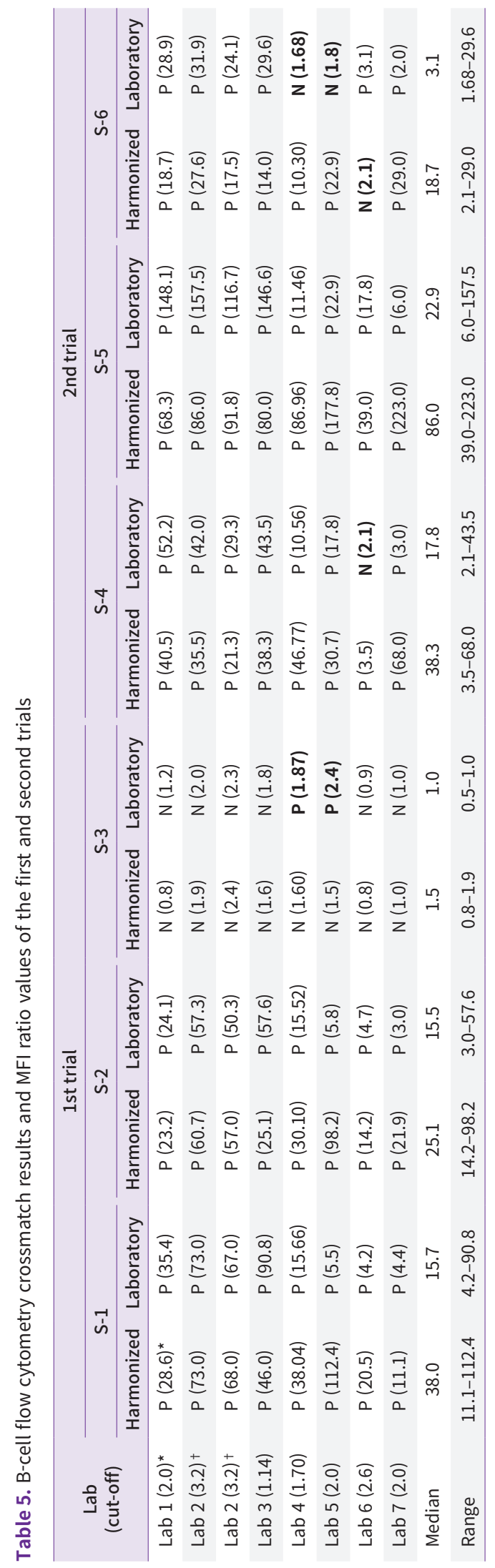

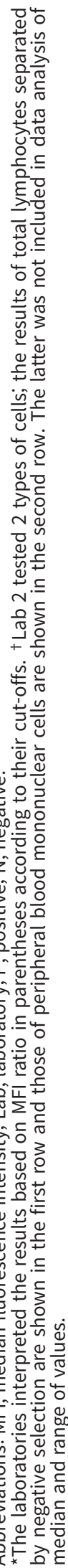

\section{3) MFI ratio의 변이}

MFI ratio는 1 차와 2 차 평가 모두에서 기관 1 과 기관 3 에서는 기존검사법보다 공통검사법의 결과를 낮게 보고하였는데, 기존검 사법에서 혈청량이 세포부유액의 양보다 2 배, 3 배로 더 많이 사용 하는 기관이었다(Table 3). 그러나 세포부유액에 비해 혈청량이 적거나 동일했던 기관 5 와 기관 7 의 경우에는 기존검사법의 결과 보다 공통검사법의 결과에서 양성 검체의 MFI ratio가 증가한 결 과를 보였다. 기관 2에서는 밀도구배원심법으로 말초혈액단핵구 를 분리하는 방법과 음성 선택방법의 시약을 이용하여 총 림프구 를 분리하는 방법 두 가지를 동시에 시행하였는데, 양성 및 음성 결과와 MFI ratio 결과의 유의한 차이는 관찰되지 않았다(Tables 4, 5).

1 차와 2차 평가결과 기관 간의 MFI ratio의 CV는 음성 결과를 보이는 혈청을 제외하고는 기존검사법으로 검사를 한 경우보다 공 통검사법으로 검사를 시행한 경우 유의하게 낮았다 $(P=0.0003)$. 특히 1 차 평가결과보다 2차 평가결과에서 기존검사법 간은 차 이가 없었으나 공통검사법 간의 $\mathrm{CV}$ 는 유의하게 감소하였다 $(P=0.6667$ vs. $P=0.01431)$. 위음성이나 위양성 결과를 보고한 기 관을 제외하고 $\mathrm{T}$ 세포와 $\mathrm{B}$ 세포 $\mathrm{FCMX}$ 에서 공통검사법과 기준검사 법의 CV를 산정하여 보았다(Fig. 2). T세포 FCXM 1차 평가에서 S-1의 기존검사법과 공통검사법의 CV는 각각 $98.6 \%$ 와 $75.6 \%$ 였 고, S-2의 CV는 각각 55.2\%와 52.3\%였는데, 2차 평가결과 S-4 의 기존검사법과 공통검사법의 $\mathrm{CV}$ 는 각각 $83.2 \%$ 와 $39.7 \%$ 였고, $\mathrm{S}-5$ 의 CV는 각각 $93.6 \%$ 와 $55.2 \%$ 였다. B세포 FCXM 1차 평가에 서 S- 1 의 기존검사법과 공통검사법의 CV는 각각 $95.2 \%$ 와 $66.9 \%$ 였고, S-2의 CV는 각각 $88.3 \%$ 와 $69.0 \%$ 였는데, 2차 평가결과 S-4 의 기존검사법과 공통검사법의 CV는 각각 $65.4 \%$ 와 $53.4 \%$ 였고, S-5의 CV는 각각 $88.5 \%$ 와 $57.6 \%$ 였으며, S-6의 CV는 $68.7 \%$ 와 $34.5 \%$ 였다.

\section{고찰}

본 연구는 FCXM 표준화를 위한 선제적 연구로서 7개의 참여기 관 간 검사방법의 차이를 파악하고 국내외 검사법을 비교하여 공 통검사법을 결정한 후 동일한 검체를 사용하여 각 기관 간 차이를 최소화한 상태에서 동일한 세포와 혈청 검체를 사용하여 FCXM을 시행하였다. 그 결과, 공통검사법이 기관 간의 차이를 감소시킬 수 있음을 확인하였고 일부 기관에서는 공통검사법이 기존검사법에 비하여 음성 및 양성 결과 판정에 더 우수함을 확인하였다.

자발적으로 참여를 결정한 7 개 기관은 기존에 사용하고 있는 FCXM 검사법이 매우 다양하였는데, 이는 이전 국내 현황을 조사 하였을 당시 확인된 바 있었다[11]. 공통검사법을 결정하기 위해 


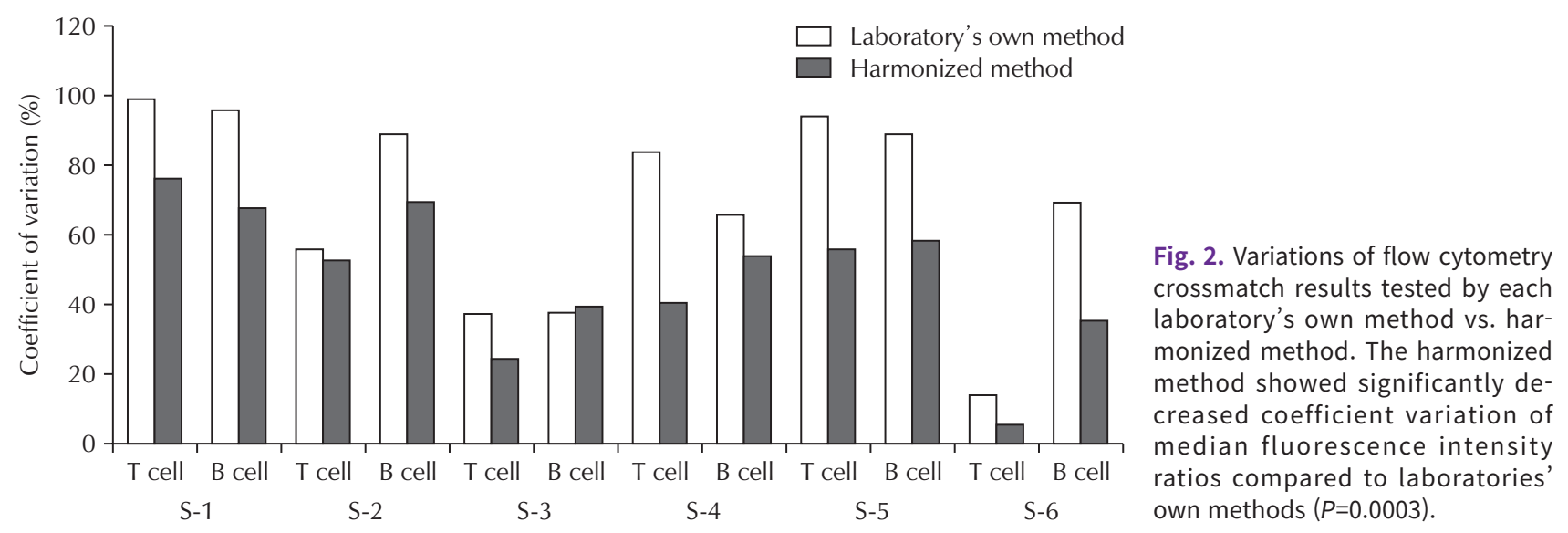

서는 ASHI 가이드라인을 참조하되[12], 검체량 및 처리시간을 단 축하여 검사의 효율성을 증대시키고, 다기관 검증을 통해 제안한 방법이 성공적임을 보고한 캐나다 Liwski 그룹의 방법을 검토 후 상당 부분 수용하였다[13].

세포분리 방법과 사용하는 세포의 종류는 각 기관에서 사용하 는 장비 및 시약이 달라 일치시키기 어려워 결과에 미치는 영향을 비교하기 위해 기관 2에서 밀도구배원심법으로 말초혈액단핵구 를 분리하는 방법과 음성 선택방법의 시약을 이용하여 총 림프구 를 분리하는 방법 두 가지를 동시에 시행하였는데, 양성 및 음성 결과와 MFI ratio 결과의 유의한 차이는 관찰되지 않았다. 따라서 $\mathrm{FCXM}$ 을 위한 세포 준비과정에서 분리를 위한 방법의 차이와 말 초혈액단핵구 또는 림프구를 이용하는 것은 검사결과에 미치는 영 향이 적을 것으로 판단된다. 그러나 정상인이 아니고, 림프구 수나 비율이 매우 낮은 뇌사자 검체의 경우 말초혈액단핵구에는 림프구 순도가 낮아 유세포분석 시 충분한 수의 림프구 분석에 문제가 있 을 가능성이 있을 것으로 판단된다.

세포 수와 혈청의 비율은 검사결과에 영향을 미칠 수 있는 주요 요인이다. 세포 수를 정확하게 계수하지 않고 혈청량에 비해 지나 치게 많은 세포를 반응시킬 경우 위음성 결과를 초래할 수 있으며, 세포부유액의 양과 혈청량에 따라 혈청이 희석되는 정도가 달라 예민도에 영향을 미칠 수 있어 ASHI 검사방법은 동량을 사용하는 방법을 제시하고 있다[12]. 본 연구결과에서도 기존검사법에서 세 포부유액 대비 혈청량이 많은 기관 1 과 기관 3 의 경우에는 기존검 사법 대비 공통검사법의 결과에서 MFI ratio가 감소하였으며, 기 존검사법에서 혈청량이 세포부유액보다 $1 / 5$ 로 적었던 기관 5 의 경우에는 기존검사법 대비 공통검사법의 결과에서 MFI ratio가 현저히 증가하였다. 검사실의 상황에 따라 최적의 검사결과를 얻 을 수 있는 검사방법을 설정하는 과정이 꼭 필요하지만, 혈청량과 세포부유액은 검사결과에 영향을 미치는 주요한 요인이므로, 동량
혹은 유사한 양을 사용하는 방법으로 검사를 시행하면 적절한 검 사결과를 얻을 수 있을 것으로 기대된다.

$\mathrm{B}$ 세포는 표면의 Fc-receptor와 자가항체 등으로 인해 비특이 적 형광이 관찰되기도 하는데, $\mathrm{B}$ 세포 $\mathrm{FCXM}$ 의 민감도와 특이도 의 개선을 위해 pronase를 처리하여 Fc-receptor를 제거하고 검 사를 시행한다[14]. 그렇지만 pronase 처리를 한 세포로 T세포 $\mathrm{FCXM}$ 을 시행하게 되면 간혹 위양성 결과를 초래할 수 있다는 보 고가 있어 pronase 적정 농도의 결정이나 결과 해석 시에 주의가 필요하다[15,16]. 참여기관 중 pronase를 처리한 세포로 T세포 와 $\mathrm{B}$ 세포 $\mathrm{FCXM}$ 결과를 보고하는 기관 5 와 기관 6 의 경우 $\mathrm{T}$ 세포 $\mathrm{FCXM}$ 의 기존검사법에서 위양성 보고는 없었다. 참여기관 4 의 경 우에는 기존검사법에서 pronase를 처리하지 않았는데, 1 차 평가 의 S-3과 2차 평가의 S-6에서 각각 위양성과 위음성을 보고하였 다. 공통검사법 결과는 각각 음성과 양성으로 보고하여 pronase 를 처리하여 B세포 FCXM을 시행하는 것이 정확한 결과를 보고하 기 위해 필요한 과정임을 확인할 수 있었다.

합의 결과와의 일치율은 기존검사법에 비해 공통검사법에서 더 높았으나, 기관 6 의 경우에는 1 차와 2 차 평가에 걸쳐 반복적으로 위음성 또는 위양성 결과를 보고하여 검사방법의 전체 시행과정 을 전반적으로 검토하기로 하였다. 기관 6 의 결과를 제외하면, 공 통검사법으로 시행한 결과와 합의 결과 간의 일치율은 1 차와 2 차 평가 모두에서 $100 \%$ 였다. 기존검사법에서 불일치하는 결과는 위 음성 보고가 5건이었고 위양성 보고는 2건이었는데, MFI ratio 10 이하의 중등도 양성 검체에서 보고되었다. 기존검사법에서 위음성 을 보고한 대부분의 기관(기관 5, 6, 7)은 IgG-FITC의 종류가 공통 검사법과 달라 2차 항체에 의한 영향의 가능성이 있음을 확인하였 다. 공통검사법으로 시행한 검사결과는 기존검사법보다 개선되었 음을 확인하였으나, MFI ratio는 공통검사법으로 시행한 결과라도 각 기관별로 여전히 다양하였다. 그럼에도 불구하고 공통검사법으 
로 검사를 시행한 경우에는 각 기관 간의 MFI ratio의 CV가 유의 하게 낮았으며, 1차 평가결과보다 2차 평가결과에서 유의하게 감 소하였다. 변경이 가능한 검사요소에 대해 기관 간의 차이를 줄이 는 공통검사법을 적용함으로써 검사의 정확성을 향상시킬 수 있을 뿐 아니라 MFI ratio와 같은 정량계수의 변이도 줄일 수 있음을 확 인하였다. 또한 1 차 평가 후 개선점의 공유와 2 회에 걸친 평가를 통해 검사 담당자의 공통검사법에 대한 숙련도가 CV 감소에 영향 을 미쳤을 것으로 생각된다.

본 연구를 통해 각 검사실마다 다양한 방법으로 FCXM 검사를 시행하고 있음을 파악하였으며, 주요 검사방법과 시약을 일치시 킴으로써 검사실 간 결과의 변이를 감소시키고 검사성능을 향상 시킬 수 있음을 알 수 있었다. 현재 국내 신빙도조사사업의 FCXM 결과에서 강양성과 음성 검체를 제외하고는 $80 \%$ 이상의 합의 결 과를 얻기 어렵고 각 기관에서 보고하는 MFI ratio의 범위가 매우 넓어 반정량적 결과 평가가 어려운 현황을 개선하는 데 도움이 될 수 있을 것으로 기대된다. 그렇지만 여전히 검사실 간의 결과 차이 가 있는데, 이는 검사 담당자의 검사방법에 대한 이해와 교육을 통 해 검사과정을 향상시키고, 현재 각 기관에서 사용하고 있는 다양 한 cut-off를 평가하여 적정 cut-off를 산정하고 적용할 필요가 있 다. 본 연구에서는 공통방법은 제안하였으나 공통 cut-off에 대한 평가는 시행하기 못하였는데, 향후 이에 대한 추가 연구가 필요하
겠다. 또한 본 연구에 참여한 7 개 기관 이외에 FCXM 검사를 시행 하는 34 개 기관으로 공통검사법을 확대함으로써 검사의 표준화를 이룰 수 있는 방안이 필요할 것이다. FCXM의 결과에 따라 장기이 식 여부뿐만 아니라 치료방침의 결정 등이 영향을 받으므로 검사 방법의 표준화 작업을 통해 검사결과의 정확성과 신뢰도를 높이기 위한 지속적인 노력이 필요하겠다.

\section{감사의 글}

이 논문은 대한임상검사정도관리협회 2019년 학술연구비 (2019-03) 지원에 의해 이루어진 것이다.

\section{ORCID}

Younhee Park https://orcid.org/0000-0001-8458-1495 Myoung Hee Park https://orcid.org/0000-0003-1272-2695 Borae G. Park https://orcid.org/0000-0001-9710-9253 Eun-Jee Oh https://orcid.org/0000-0001-5870-915X Hae In Bang https://orcid.org/0000-0001-7854-3011 Jong-Han Lee https://orcid.org/0000-0003-4036-8443 Eun-Suk Kang https://orcid.org/0000-0001-6386-6520

\section{REFERENCES}

1. Garovoy MR, Rheinschmidt MA, Bigos M, Perkins H, Colombe B, Feduska N, et al. Flow cytometry analysis: a high technology cross-match technique facilitating transplantation. Transplant Proc 1983;15:1939-44.

2. Graff RJ, Buchanan PM, Dzebisashvili N, Schnitzler MA, Tuttle-Newhall J, Xiao H, et al. The clinical importance of flow cytometry crossmatch in the context of CDC crossmatch results. Transplant Proc 2010;42:3471-4.

3. Tinckam K. Histocompatibility methods. Transplant Rev (Orlando) 2009;23:80-93.

4. Ayna TK, Soyoz M, Kurtulmus Y, Dogan SM, Ozy Imaz B, Tugmen C, et al. Comparison of complement-dependent cytotoxic and flow-cytometry crossmatch results before cadaveric kidney transplantation. Transplant Proc 2013;45:878-80.

5. Kang ES. Annual report of Korean Association of External Quality Assessment Service on histocompatibility testing (2018). J Lab Med Qual Assur 2019;41:130-52.

6. Lentine KL, Graff RJ, Xiao H, Modanlou KA, Salvalaggio PR, Brennan DC, et al. Flow cytometry crossmatch before kidney transplantation in contemporary practice: target cell utilization, results patterns, and associated long-term graft survival. Clin Transpl 2008:253-66.

7. Gebel HM, Bray RA, Nickerson P. Pre-transplant assessment of donor-reactive, HLA-specific antibodies in renal transplantation: contraindication vs. risk. Am J Transplant 2003;3:1488-500.

8. Piatosa B, Rubik J, Grenda R. Is positive flow cytometric cross-match a risk factor for early cadaveric kidney graft dysfunction? Transplant Proc 2006;38:53-5.

9. Graff RJ, Xiao H, Schnitzler MA, Ercole P, Solomon H, Pessin T, et al. The role of positive flow cytometry crossmatch 
in late renal allograft loss. Hum Immunol 2009;70:502-5.

10. Tian J, Li D, Alberghini TV, Rewinski M, Guo N, Bow LM. Pre-transplant low level HLA antibody shows a composite poor outcome in long-term outcome of renal transplant recipients. Ren Fail 2015;37:198-202.

11. Yu S, Kang ES, Park MH. A questionnaire survey of HLA crossmatch tests in Korea (2015). Lab Med Online 2017;7:14756.

12. Hamrick C, Lebeck L. Flow cytometry T cell and B cell crossmatching. In: Hahn AB, Land GA, Strothman RM, editors. ASHI laboratory manual. 4th ed. Mount Laurel (NJ): American Society for Histocompatibility and Immunogenetics, 2000:VI.B.4.1-VI.B.4.5.

13. Liwski RS, Greenshields AL, Conrad DM, Murphey C, Bray RA, Neumann J, et al. Rapid optimized flow cytometric crossmatch (FCXM) assays: the Halifax and Halifaster protocols. Hum Immunol 2018;79:28-38.

14. Vaidya S, Cooper TY, Avandsalehi J, Barnes T, Brooks K, Hymel P, et al. Improved flow cytometric detection of HLA alloantibodies using pronase: potential implications in renal transplantation. Transplantation 2001;71:422-8.

15. Hetrick SJ, Schillinger KP, Zachary AA, Jackson AM. Impact of pronase on flow cytometric crossmatch outcome. Hum Immunol 2011;72:330-6.

16. Park H, Lim YM, Han BY, Hyun J, Song EY, Park MH. Frequent false-positive reactions in pronase-treated T-cell flow cytometric cross-match tests. Transplant Proc 2012;44:87-90. 